\title{
COMPARATIVE TAPHONOMY AND FAUNAL COMPOSITION OF SHELLY CHENIERS FROM NORTHEASTERN BAJA CALIFORNIA, MEXICO
}

\section{TAFONOMÍA COMPARATIVA Y COMPOSICIÓN FÁUNICA DE CHENIERS DE CONCHAS DEL NORESTE DE BAJA CALIFORNIA, MÉXICO}

\author{
Michal Kowalewski \\ Karl W. Flessa \\ Department of Geosciences \\ University of Arizona, \\ Tucson, Arizona \\ USA
}

Recibido en julio de 1994: aceptado en marzo de 1995

\begin{abstract}
This report presents the results of comparative taphonomic and faunal analyses of shelly cheniers (mollusk-dominated lag concentrations) from the tidal flats of northeastern Baja California, Mexico. Three generations of cheniers that differ in age and in the duration and complexity of their taphonomic history were sampled for taphonomic and faunal analyses. The three generations, although all dominated by the bivalve mollusk Mulinia coloradoensis, differ significantly in their taxonomic composition due to taphonomic and/or biological differences. Taphofacies analysis of 4,334 shells of $M$. coloradoensis described by nine variables indicated that the shells accumulated in the cheniers are rarely affected by biological processes and moderately affected by physical processes. The shells collected from the chenier surface have poorer preservation than the subsurface ones, indicating that taphonomic degradation is mostly a surface phenomenon. Multivariate analyses discriminate the chenier generations even when the poorly preservable luster variables are excluded from the analysis. Chenier shelly assemblages are taphonomically distinct from assemblages formed in other marine environments. They are characterized by a very low intensity of bioerosion and encrustation.
\end{abstract}

Key words: taphofacies analysis, cheniers, bivalves, Baja California, Holocene.

\section{RESUMEN}

Este trabajo presenta los resultados de la tafonomía comparativa y los análisis faúnicos de los cheniers de conchas (concentraciones residuales dominadas por moluscos) de las planicies de marea del noreste de Baja California, México. Se muestrearon tres generaciones de cheniers, que difieren tanto en edad como en la duración y complejidad de sus historias tafonómicas, para efectuar sus análisis tafonómico y fáunico. Las tres generaciones, aunque todas dominadas por el molusco bivalvo Mulinia coloradoensis, difieren significativamente en sus composiciones tafonómicas debido a diferencias tafonómicas y/o biológicas. El análisis de tafofacies de 4,334 conchas de $M$. coloradoensis, descrito por nueve variables, indicó que las conchas acumuladas en los cheniers son raramente afectadas por procesos biológicos pero moderadamente afectadas por procesos físicos. Las conchas recolectadas en la superficie del chenier se preservaron de forma más pobre que las de la subsuperficie, lo cual indica que la degradación tafonómica es principalmente un fenómeno superficial. Los análisis de multivariables distinguen las generaciones de cheniers aun cuando se excluyan en ellos las variables de lustre pobremente preservadas. Los conjuntos de conchas cheniers son tafonómicamente distìntos 
de los conjuntos formados en otros ambientes marinos. Se caracterizan por intensidades muy bajas de bioerosión e incrustación.

Palabras clave: análisis de tafofacies, cheniers, bivalvos, Baja California, holoceno.

\section{INTRODUCTION}

Taphonomic (preservational) variation of fossil assemblages reflects, to a significant degree, the differences in rate, mode and environment of their burial. Taphofacies analysis, a discrimination of paleoenvironments through comparative analysis of taphonomic traits (Speyer and Brett, 1986; Brett and Baird, 1986), uses such taphonomic variation to interpret ancient depositional systems. Taphofacies has already proven to be a useful concept in paleontology (e.g., Speyer and Brett, 1986; Brandt, 1989). It has also been successfully tested in several actualistic studies (Parsons and Brett, 1991).

This study presents the results of a comparative taphonomic analysis of shell accumulations concentrated in Holocene cheniers (beach ridges) of northeastern Baja California (fig. 1) (see also Meldahl, 1993, 1995, for taphonomic and sedimentological studies on PlioPleistocene cheniers from Baja California). These mollusk-dominated lag concentrations (sensu Kidwell, 1991) are forming in a sedimentologically and biologically uniform environment and, if preserved in the fossil record, would not be distinguishable in terms of biofacies and lithofacies. However, because the cheniers vary in the length and complexity of their taphonomic history, the assemblages may potentially be discriminated in terms of taphofacies. In order to test this prediction, a detailed comparative taphonomic analysis was undertaken to see if shelly ridges of a different age can indeed be discriminated. Can taphofacies be discriminated among the shelly assemblages of similar origin (in this case chenier-type lag concentrations) that differ in their history prior to burial?

The taphofacies analysis presented here has been undertaken to investigate: the utility of the exploratory taphofacies approach, the taphonomic characteristics of chenier-type deposits and the taphonomic clock.

\section{INTRODUCCIÓN}

La variación tafonómica (preservación) de los conjuntos fósiles refleja, hasta cierto grado, las diferencias en tasa, modo y ambiente de enterramiento. El análisis de tafofacies, discriminación de paleoambientes a través del análisis comparativo de cualidades tafonómicas (Speyer y Brett, 1986; Brett y Baird, 1986), utiliza esa variación tafonómica para interpretar sistemas antiguos de depósito. I a tafofacies ha demostrado ser un concepto útil en paleontología (e.g., Speyer y Brett, 1986; Brandt, 1989). Tambićn se ha probado con éxito su utilidad en varios estudios actuales (Parsons y Brett, 1991).

Este estudio presenta los resultados de un análisis comparativo de las acumulaciones de conchas concentradas en cheniers (crestas de playa) del holoceno del noreste de Baja California (fig. 1) (véase Meldahl, 1993, 1994, sobre estudios tafonómicos y sedimentológicos de cheniers del pliopleistoceno de Baja California). Estas concentraciones residuales (sensu Kidwell, 1991) dominadas por moluscos se forman en un ambiente sedimentológica y biológicamente uniforme y, si se preservaran en el registro fósil, no serían distinguibles en términos de biofacies y litofacies. Sin embargo, dado que la historia tafonómica de los cheniers varía en extensión y complejidad, los conjuntos pueden ser potencialmente discriminados en términos de tafofacies. Con objeto de probar esta predicción, se efectuó un análisis tafonómico comparativo detallado, para ver si las crestas de conchas de diferente edad pueden ser efectivamente discriminadas. ¿Es posible descriminar tafofacies entre los conjuntos de conchas de origen similar (en este caso, concentraciones residuales tipo chenier) que difieren en su historia previa al enterramiento?

El análisis presentado se propuso investigar: la utilidad del acercamiento mediante exploración de tafofacies, las características de los depósitos tipo chenier, y el reloj tafonómico. 


\section{STUDY AREA AND TAPHONOMIC SETTING}

The study area is the southernmost delta plain of the Colorado River, north of San Felipe, Baja California, Mexico (fig. 1). The tidal flats of the region experience exceptionally high semi-diurnal tides that range up to $10 \mathrm{~m}$ (Thompson, 1968; Bray and Robles, 1991). The climate of the area is hot and arid with a maximum summer temperature of $50^{\circ} \mathrm{C}$ and a very low precipitation of less than $60 \mathrm{~mm}$ per year. The tidal flats are a progradational feature composed of fine-grained clastic sediments consisting predominately of silts and fine-grained sands. Several series of longitudinally oriented, coarse-grained, shell-rich, ridges occur in the area (fig. 1c). These beach ridges, or more precisely cheniers (for detailed discussion on cheniers see Augustinus, 1989), form a chenier plain: a progradational sequence of parallel ridges separated from one another by inter-ridge mudflats. The facies development of the tidal flats, discussed in great detail by Thompson (1968), has largely been controlled by the activity of the Colorado River. It may have also been controlled by subsidence (Walker and Thompson, 1968) and lateral movements (Suárez-Vidal et al., 1991) along the El Chinero fault, an enechelon transform fault that separates the tidal flats from the inland alluvial fans (Gastil et al., 1975; Suárez-Vidal et al., 1991).

The delta cheniers can be ordered chronologically into three generations that correspond to three episodes of low sediment discharge from the Colorado River. They are called here modern, submodern, and fossil cheniers. The three generations are distinguishable by their position relative to the present-day shoreline (fig. 1c), their topography (table 1) and radiocarbon-dated mollusk shells (table 1). Modern cheniers stretch along the present-day high tide line and are cut by several irregularly spaced tidal channels. They have all formed during the last seventy years when intensification of agriculture and construction of dams drastically reduced the sediment and water discharge from the Colorado River. The submodern cheniers are separated from the current

\section{ÁREA DE ESTUDIO Y ARREGLO TAFONÓMICO}

El área de estudio está en la porción más al sur de la planicie del delta del río Colorado al norte de San Felipe, Baja California, México (fig. 1). Las planicies de marea de la región experimentan mareas semidiurnas excepcionalmente altas, de hasta $10 \mathrm{~m}$ de altura (Thompson, 1986; Bray y Robles, 1991). El clima del área es caliente y árido, con temperaturas máximas en verano de $50^{\circ} \mathrm{C}$ y precipitaciones mínimas de menos de $60 \mathrm{~mm}$ por año. Las planicies de marea son de tipo progradante compuestas de sedimentos clásticos de grano fino, consistentes principalmente en limo y arena fina. Existen en el área varias series de crestas de grano grueso, ricas en conchas orientadas longitudinalmente (fig. 1c). Estas crestas de playa, o más precisamente cheniers (para una discusión detallada sobre cheniers véase Augustinus, 1989), forman una planicie chenier: secuencia progradante de crestas paralelas separadas una de otra por planicies lodosas intercrestas. El desarrollo de las facies de planicies de mareas, discutido con mayor detalle por Thompson (1968), ha sido controlado ampliamente por la actividad del río Colorado. Puede haber sido controlado también por subsidencia (Walker y Thompson, 1968) y movimientos laterales (Suárez-Vidal et al., 1991) a lo largo de la falla El Chinero, falla transformada en echelón que separa las planicies de marea de los abanicos aluviales tierra adentro (Gastil et al,, 1975; Suárez-Vidal et al., 1991).

Los cheniers del delta pueden ser ordenados cronológicamente en tres generaciones correspondientes a tres episodios de baja descarga de sedimentos del río Colorado. En este trabajo les llamamos cheniers moderno, submoderno y fósil. Las tres generaciones pueden ser reconocidas por su posición con respecto a la línea de costa actual (fig. 1c), su topografia (tabla 1) $y$ su edad fechada por radiocarbono en conchas de moluscos (tabla 1). Los cheniers modernos se extienden a lo largo de la línea de marea alta actual y son cortados por diversos canales de marea espaciados irregularmente. Éstos se han formado durante los últimos setenta años como 


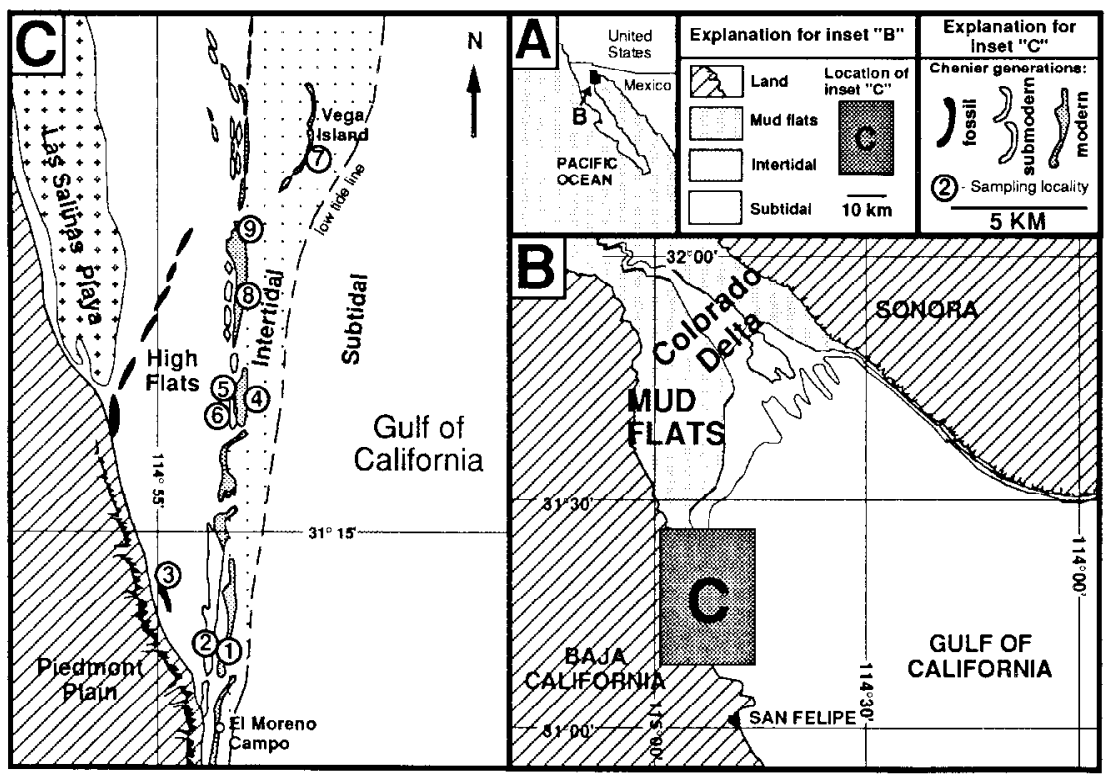

Figure 1. Schematic map of study area. A, Regional map (Baja and Gulf of California); B, Northern Gulf of California and Colorado River delta (modified after Thompson, 1968); C, Tidal flats and cheniers of study area (northeastern Baja California, Mexico).

Figura 1. Mapa de localización del área de estudio. A, mapa de la región (Baja California y golfo de California); B, parte norte del golfo de California y delta del río Colorado (modificado de Thompson, 1968); C, planicies de marea y cheniers del área de estudio (noreste de Baja California).

shoreline and modern ridges by a narrow strip of tidal flat. Radiocarbon dates suggest that they formed sometime during the last 1,500 years (table 1). The fossil cheniers are located several kilometers inland of the current shoreline. They were formed sometime between 5,000 and 2,000 years, indicating that the fossil ridges were formed earlier than the two younger generations (table 1 ).

The ability to classify the cheniers into the three age groups provides an opportunity to distinguish the ridges in terms of their taphonomic history. The taphonomic history of a chenier shell assemblage can be divided into two stages. The first, biostratinomic stage, corresponds to low discharge conditions when a new chenier is forming. This stage is dominated by transport processes in a tidal environment. The mechanical processes associated with shell transport and resultado de la intensificación de la agricultura y la construcción de presas que han reducido drásticamente la descarga de sedimentos y agua del río Colorado. Los cheniers submodernos están separados de la línea de costa actual y de las crestas modernas por un estrecho corredor de planicie de marea. Las edades de radiocarbono sugieren (tabla 1) que se formaron hace aproximadamente 1,500 años. Los cheniers fósiles se encuentran varios kilómetros tierra adentro de la línea de costa actual. Éstos se formaron hace 5,000 a 2,000 años, lo cual indica que las crestas fósiles se formaron con anterioridad a las otras dos generaciones más recientes (tabla 1).

La conveniencia de agrupar estos cheniers en tres grupos permite distinguirlos en términos de su historia tafonómica. La historia tafonómica de un conjunto de conchas tipo chenier 
Table 1. Summary of location, topography, composition, chronology and taphonomic history of the three generations of cheniers (modern, submodern and fossil) from the lower Colorado delta (Baja California, Mexico).

\begin{tabular}{|c|c|c|c|}
\hline & Modern chenier & Submodern chenier & Fossil chenier \\
\hline $\begin{array}{l}\text { Position relative to } \\
\text { the current shoreline }\end{array}$ & $\begin{array}{l}\text { Situated at the present-day } \\
\text { shoreline, the modern } \\
\text { cheniers are located near } \\
\text { the high-tide line. }\end{array}$ & $\begin{array}{l}\text { Situated from } 0.1 \text { to } 1 \mathrm{k} \\
\text { from the current shoreline, } \\
\text { the submodern cheniers } \\
\text { are separated from the } \\
\text { present-day intertidal by } \\
\text { modern ridges, tidal chan- } \\
\text { nels and inter-ridge mud- } \\
\text { flats. In a few cases, the } \\
\text { submodern cheniers di- } \\
\text { verge from or merge with } \\
\text { the modern ridges. }\end{array}$ & $\begin{array}{l}\text { Situated several kilometers } \\
\text { inland from the present- } \\
\text { day shoreline, fossil cheni- } \\
\text { ers are separated from the } \\
\text { two younger series of } \\
\text { cheniers by extensive } \\
\text { inter-ridge mudflats. }\end{array}$ \\
\hline
\end{tabular}

Topography and composition

Radiocarbon dates

Causes of chenier formation

Time of formation

Taphonomic history

One-stage taphonomic history: Biostratinomic Stage only.
Modern cheniers have a steep seaward slope, gentle back-slope and a relief of 2 to $4 \mathrm{~m}$. They are composed exclusively of shell material in the north, and they have a significant proportion of medium to coarse sand in the south. Ridges are devoid of vegetation, shell deflation pavements are rare and fragile remains (e.g., crab carapaces, echinoid tests) are common.

$690^{\prime}, 780^{1}, 825^{1}, 1,050^{2}$, $1,060^{1}, 1,240^{1}, 1,240^{\prime}$, $1,400^{1}, 1,575^{1}, 1,735^{2}$, $2,095^{2}$.

Diversion of river flow by construction of dams and increased irrigation.

Last 70 years.
Submodern cheniers have a profile and relief similar to modern ones. They are composed of shell material and medium to coarse sand. Ridges are partially covered by vegetation and shell deflation pavements. Fragile remains (e.g., crab carapaces, echinoid tests) are uncommon.

$775^{1}, 1,180^{1}, 1,225^{1}$, $1,285^{2}, 1,325^{1}, 1,350^{1}$, $1,400^{1}, 1,420^{1}, 1,500^{1}$, $1,575^{1}, 1,675^{\prime}$.

Natural diversion of the Colorado River to the Salton Trough.

Unknown, most likely less than 1,500 years.

Two-stage taphonomic history: Biostratinomic Stage and short (a few hundred years at most) Weathering Stage.
Fossil cheniers are more symmetric compared to the two younger generations of cheniers. They are also flatter with a relief of 1 to $2 \mathrm{~m}$. They are composed of shell material and medium to coarse sand. They are covered by vegetation, shell deflation pavements are common, and fragile remains are very rare.

$2,190^{\prime}, 2,460^{1}, 2,950^{\prime}$, $3,610^{2}, 4,830^{!}$.

Natural diversion of the Colorado River to the Salton Trough.

Unknown, but at least 1,500 years ago.

Two-stage taphonomic history: Biostratinomic Stage and long $(1,500$ years at least) Weathering Stage.

\footnotetext{
' Edades de radiocarbono compiladas de la literatura (para referencias véase Kowalewski et al., 1994).

${ }^{2}$ Edades de radiocarbono reportadas por Kowalewski et al. (1994).
} 
Tabla 1. Resumen de la localidad, topografia, composición, cronología e historia tafonómica de las tres generaciones de cheniers (moderno, submoderno y fósil) del bajo delta del Colorado (Baja California, México).

\begin{tabular}{llll}
\hline & Cheniers modernos & Cheniers submodernos & Cheniers fósiles \\
\hline Posición relativa a la & Están situados en la línea & Están situados de 0.1 a & Están situados varios \\
corriente costera & de costa actual y & $1 \mathrm{~km}$ de la línea de costa & kilómetros tierra adentro \\
& localizados cerca de la & actual; están separados de & de la línea de costa actual. \\
& línea de alta marea & la zona intermareal por & Extensas planicies lodosas \\
& & crestas modernas, canales & intercrestas los separan de \\
& & de marea y planicies & las series más jovenes de \\
& lodosas. En unos cuantos & cheniers.
\end{tabular}

Topografia y composición

\section{Edades de} radiocarbono

Causas de formación de los cheniers

Tiempo de formación

Historia tafonómica
Tienen una pendiente hacia el mar, acentuada pero suave hacia atrás y un relieve de 2 a $4 \mathrm{~m}$. Al norte están compuestos de conchas, al sur tienen una proporción importante de arena media a gruesa. Las crestas carecen de vegetación, los pisos de deflación de conchas son raros pero los restos frágiles son comúnes (e.g., caparazones de cangrejos, testas de equinoides).

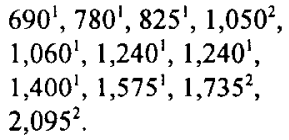

Desviación de la corriente fluvial por la construcción de presas y creciente irrigación.

\section{Últimos 70 años.}

Historia tafonómica de una sola etapa: bioestratinómica. submodernos divergen de crestas modernas o se unen a ellas.

Tienen perfil y relieve similar a los modernos y están compuestos de conchas y arena media a gruesa. Las crestas están parcialmente cubiertas por vegetación y pisos de deflación de conchas. Los restos frágiles son poco comunes (e.g., caparazones de cangrejos, testas de equinoides).

$775^{1}, 1,180^{1}, 1,225^{1}$, $1,285^{2}, 1,325^{1}, 1,350^{1}$, $1,400^{1}, 1,420^{1}, 1,500^{1}$, $1,575^{1}, 1,675^{1}$.

Desviación natural del río Colorado al mar de Salton.

Desconocida, probablemente menos de 1,500 años.

Historia tafonómica de dos etapas: bioestratinómica e intemperismo (la segunda es breve, unos cientos de afios, cuando mucho).
Son más simétricos que las dos generaciones más jóvenes. Son también más planos y con 1 a $2 \mathrm{~m}$ de relieve. Están compuestos por conchas y arena media a gruesa y cubiertos por vegetación. Los pisos de deflación de concha son comúnes y los restos frágiles son muy raros.
$2,190^{1}, 2,460^{\mathrm{I}}, 2,950^{\mathrm{I}}$, $3,610^{2}, 4,830^{\prime}$.

Desviación natural del río Colorado al mar de Salton.

Desconocida, pero al menos hace 1,500 años.

Historia tafonómica de dos etapas: bioestratinómica e intemperismo (la segunda es larga, al menos 1,500 años)

\footnotetext{
' Edades de radiocarbono compiladas de la literatura (para referencias véase Kowalewski et al., 1994).

${ }^{2}$ Edades de radiocarbono reportadas por Kowalewski et al. (1994).
} 
erosion, such as abrasion and fragmentation, and biological agents such as bioerosion and encrustation are dominant taphonomic forces. The biostratinomic stage results in the formation of allochthonous lag accumulations that, as suggested by the range of radiocarbon dates (table 1), are time-averaged on a scale of one thousand to three thousand years. The second stage, weathering, begins when the increase in sediment discharge from the Colorado River reactivates the progradation of the tidal flats. The mechanical processes of the biostratinomic stage are replaced by a dramatically different set of taphonomic agents associated with weathering and winnowing in the subaerial hot and dry environment. The most important taphonomic factors of the weathering stage include heating by the sun, drastic daily temperature fluctuations, dissolution by meteoric waters, eolian winnowing and abrasion, and the action of vegetation.

Modern cheniers have a one-stage history of biostratinomic processes. Submodern cheniers have largely completed the biostratinomic stage and have entered a transition period (they are still affected by high spring tides and the action of tidal channels but weathering, winnowing and vegetation have become increasingly important). Fossil cheniers completed the biostratinomic stage long ago and have undergone weathering, winnowing, and disruption by vegetation for many hundreds of years. Given the different taphonomic histories of the cheniers, one might expect some variation in preservation of mollusk shells. Modern, submodern and fossil cheniers differ in the length and complexity of their taphonomic history. Do their constituent shells reflect this variation?

\section{METHODS}

Sixty-one bulk samples were collected from nine localities (fig. 1c) in February 1991 and March 1992. Forty-eight (79\%) of the samples were collected from the surface and $13(21 \%)$ from the subsurface of the cheniers. Surface samples comprised the uppermost $5 \mathrm{~cm}$ of sediment sampled from an area of approximately puede ser dividida en dos etapas. La primera etapa bioestratinómica, corresponde a las condiciones de descarga baja, cuando se está formando un nuevo chenier. Esta etapa está dominada por procesos de transporte en un ambiente mareal. Los procesos mecánicos asociados con el transporte y erosión de conchas, como abrasión y fragmentación, y los agentes biológicos, como bioerosión e incrustación, son las fuerzas tafonómicas dominantes. De la etapa bioestratinómica resulta acumulación de depósitos residuales alóctonos que, como lo sugiere el intervalo de edades de radiocarbono (tabla 1), están temporalmente espaciados entre mil y tres mil años. La segunda etapa, de intemperismo, comienza cuando la descarga de sedimentos del río Colorado se incrementa y reactiva la progradación de las planicies de marea. Los procesos mecánicos de la etapa bioestratinómica son reemplazados por un conjunto de agentes tafonómicos dramáticamente diferentes asociados al intemperismo y la acción eólica en el ambiente subaéreo caliente y seco. Los factores tafonómicos más importantes de la etapa de intemperismo son calentamiento por el sol, drásticas fluctuaciones diarias de temperatura, disolución de aguas meteóricas, acción eólica, abrasión y la acción de la vegetación.

La historia de los procesos bioestratonómicos de los cheniers modernos es de sólo una etapa. Los cheniers submodernos han completado ampliamente la etapa bioestratinómica y han iniciado un periodo de transición (siguen afectados por mareas ascendentes altas y la acción de los canales de mareas, pero el intemperismo, acción eólica y vegetación han cobrado importancia). Los cheniers fósiles han completado la etapa bioestratinómica tiempo atrás y han sufrido la etapa de intemperismo, acción eólica y ruptura por vegetación durante varios cientos de años. Dadas las diferencias en historia tafonómica de los cheniers, uno debería esperar ciertas variaciones en la preservación de las conchas de moluscos. Los cheniers modernos, submodernos y fósiles difieren en la extensión $\mathrm{y}$ complejidad de su historia tafonómica. ¿Se refleja esta variación en las conchas que los forman? 
$0.01 \mathrm{~m}^{2}(0.3 \times 0.3 \mathrm{~m})$. Subsurface samples of comparable size were collected at depths between $0.3-0.5 \mathrm{~m}$ below the chenier surface.

The samples were first analyzed for their taxonomic composition. Shell material was first isolated by wet-sieving bulk samples with a $5 \mathrm{~mm}$ screen, and subsequently, by dry sieving with a $12.5 \mathrm{~mm}$ screen. Complete shells were then separated from the shell fragments. Any fragment of a shell that included the umbo (in the case of bivalves) or the tip of the spine (in the case of gastropods) was considered as a complete specimen. All specimens were counted. A single bivalve valve was considered as half of a specimen. Whenever possible, the shells were identified to the species level.

Taphonomic analysis was restricted to a single bivalve species Mulinia coloradoensis. Mulinia coloradoensis dominates a majority of samples and it is the only species well represented in all the samples. By using $M$. coloradoensis as a target species, $84 \%$ of all specimens were considered. For each of the samples, 100 randomly chosen specimens of $M$. coloradoensis were described. For samples containing less than 100 specimens ( 23 out of 61 samples, $38 \%$ ) all shells present in the sample were included. The taphonomic properties of the specimens were described using taphonomic grades, which are arbitrary ranks that measure the preservational qualities of specimens on an ordinal scale. They were defined separately for the nine taphonomic features. They include two biological features (bioerosion and encrustation), four mechanical features (fragmentation, cracking, peeling and edge preservation) and three luster features describing the degradation of the shell surface (external luster, internal luster, and internal features). Three classes were erected for each taphonomic property, where 0 denotes best preservation, 1 intermediate and 2 poorest. A reference collection was created for each property and was used to classify each of the 4,334 specimens from 61 samples from nine localities.

All analyses and statistical tests were performed using Statistical Analysis System (SAS) (SAS Institute Inc., 1989, 1990) at the University of Arizona RVAX interactive system. The

\section{MÉTODOS}

Se recolectaron 61 muestras en nueve localidades (fig. 1c), en febrero de 1991 y marzo de 1992 . Cuarenta y ocho de ellas $(79 \%)$ fueron recolectadas de la superficie de los cheniers y $13(21 \%)$ en la subsuperficie. Las muestras de la superficie provienen de los $5 \mathrm{~cm}$ superiores del sedimento recolectado en un área de aproximadamente $0.01 \mathrm{~m}^{2}(0.3 \times 0.3 \mathrm{~m})$. Las muestras subsuperficiales de tamaño comparable fueron recolectadas a profundidades de 0.3 a $0.5 \mathrm{~m}$ por debajo de la superficie del chenier.

Primero, se analizó la composición taxonómica de las muestras. Las conchas fueron separadas mediante tamizado húmedo a granel en una malla de $5 \mathrm{~mm}$, y posteriormente, por tamizado en seco en una malla de $12.5 \mathrm{~mm}$. Luego se separaron las conchas completas de las fragmentadas. Los fragmentos de conchas que incluyeron el umbo (en el caso de bivalvos) o la punta de la espina (en el caso de los gasterópodos) fueron considerados como especímenes completos. Todos los ejemplares fueron contados. Una valva única de bivalvo fue considerada como medio individuo. Siempre que fue posible, las conchas fueron identificadas a nivel de especie.

El análisis tafonómico se limitó a una sola especie de bivalvos Mulinia coloradoensis. Ésta domina la mayoría de las muestras y es la única especie bien representada en todas. Al usar $M$. coloradoensis como especie objetivo, $84 \%$ de los especímenes fueron considerados. Para cada una de las muestras, se describieron 100 ejemplares de esta especie, escogidos al azar. En las muestras que contuvieron menos de 100 individuos de esta especie ( 23 de 61 muestras $38 \%$ ) se incluyeron todas las conchas presentes. Las propiedades tafonómicas de los especímenes fueron descritas usando grados tafonómicos, como categorías arbitrarias de medida de las cualidades de preservación de los especímenes en una escala ordinal. Éstas se definieron separadamente para las nueve características tafonómicas, e incluyen dos características biológicas (bioerosión e incrustación), cuatro rasgos mecánicos (fragmentación, fractu- 
multivariate techniques include cluster analysis (the associations were generated using the unweighted pair-group method with arithmetic averages; similarity is expressed as squared Euclidean distance), principal component analysis (PCA) and canonical variate analysis (CVA). The PCA was used as an independent exploratory technique and as a method to assess the validity of the associations (Dunteman, 1989, p.78-79) generated in cluster analysis.

\section{TAXONOMIC ANALYSIS}

\section{Results}

The taxonomic data totaled 7,870 specimens $(14,966$ valves of bivalves and 387 gastropod shells) divided among 33 taxa. Raw data are available in Kowalewski et al. (1994). Thirteen bivalve valves could not be identified. Figure 2 shows the results of cluster analysis for the nine localities and the 16 most abundant taxa. The localities cluster in two distinct groups. The first group consists solely of locality 3 , which is the only locality that represents the fossil chenier. The drastic difference between locality 3 and all other localities is an effect of the relatively lower abundance of $M$. coloradoensis in this locality (fig. 2). In addition, locality 3 includes three taxa that are rare in all the other localities: Ostrea spp., Crucibulum spp. and Glycymeris sp. The second group includes all the other localities. These eight localities represent both modern and submodern ridges and are all dominated by one bivalve species: $M$. coloradoensis (from $76 \%$ in locality 5 up to $95 \%$ in locality 8 ). The second most common taxon, Chione fluctifraga, comprises from $0.3 \%$ (in locality 9 ) to $22 \%$ (in locality 5 ) of the specimens. Modern and submodern localities can be subdivided further into three secondorder clusters (fig. 2). These associations are mostly controlled by changes in the relative abundance of $M$. coloradoensis. Two of the three secondary clusters group localities according to their relative age. However, the left cluster (localities with $85-90 \%$ of $M$. coloradoensis) groups a submodern locality (6) together with two modern localities $(1,7)$. This ramiento, desconchamiento y preservación de las orillas) y tres caracteristicas de lustre, que describen la degradación de la superficie de la concha (lustres externo e interno y apariencia interna). Para cada propiedad tafonómica se erigieron tres clases en las que 0 denota la mejor preservación, 1 la intermedia y 2 la más pobre. Para cada propiedad se creó una colección de referencia que fue usada para clasificar cada uno de los 4,334 ejemplares de las 61 muestras de las nueve localidades.

Todos los análisis y pruebas estadísticas se realizaron con el Sistema de Análisis Estadístico (SAS) (SAS Institute Inc., 1989, 1990) del sistema interactivo RVAX, de la Universidad de Arizona. Las técnicas de multivariables incluyen análisis de conjuntos (la asociación de conjuntos se generó con el método de relación promedio, método de grupos pares sin ponderar, UPGMA, usando promedios aritméticos; la similitud es expresada como el cuadrado de la distancia euclidiana), análisis de componente principal (PCA) y análisis de variable canónica (CVA). El PCA fue usado como técnica exploratoria independiente y como un método para establecer la validez de las asociaciones (Dunteman, 1989, pp. 78-79) generadas en el análisis de conjuntos.

\section{ANÁLISIS TAXONÓMICO}

\section{Resultados}

Los datos taxonómicos totalizaron 7,870 especímenes (14,966 valvas de bivalvos y 387 conchas de gasterópodos) divididas entre 33 taxa. Los datos originales se presentan en Kowalewski et al. (1994). Trece valvas de bivalvos no pudieron ser identificadas. La fig. 2 muestra los resultados del análisis de conjuntos de las nueve localidades y los 16 taxa más abundantes. Las localidades forman dos grupos bien definidos. El primero es la localidad 3 por sí sola; la única localidad que representa el chenier fósil. Las drásticas diferencias entre la localidad 3 y el resto de las localidades son resultado de la relativamente poca abundancia de M. coloradoensis en esta localidad (fig 2). Además, la localidad 3 incluye tres taxa que 


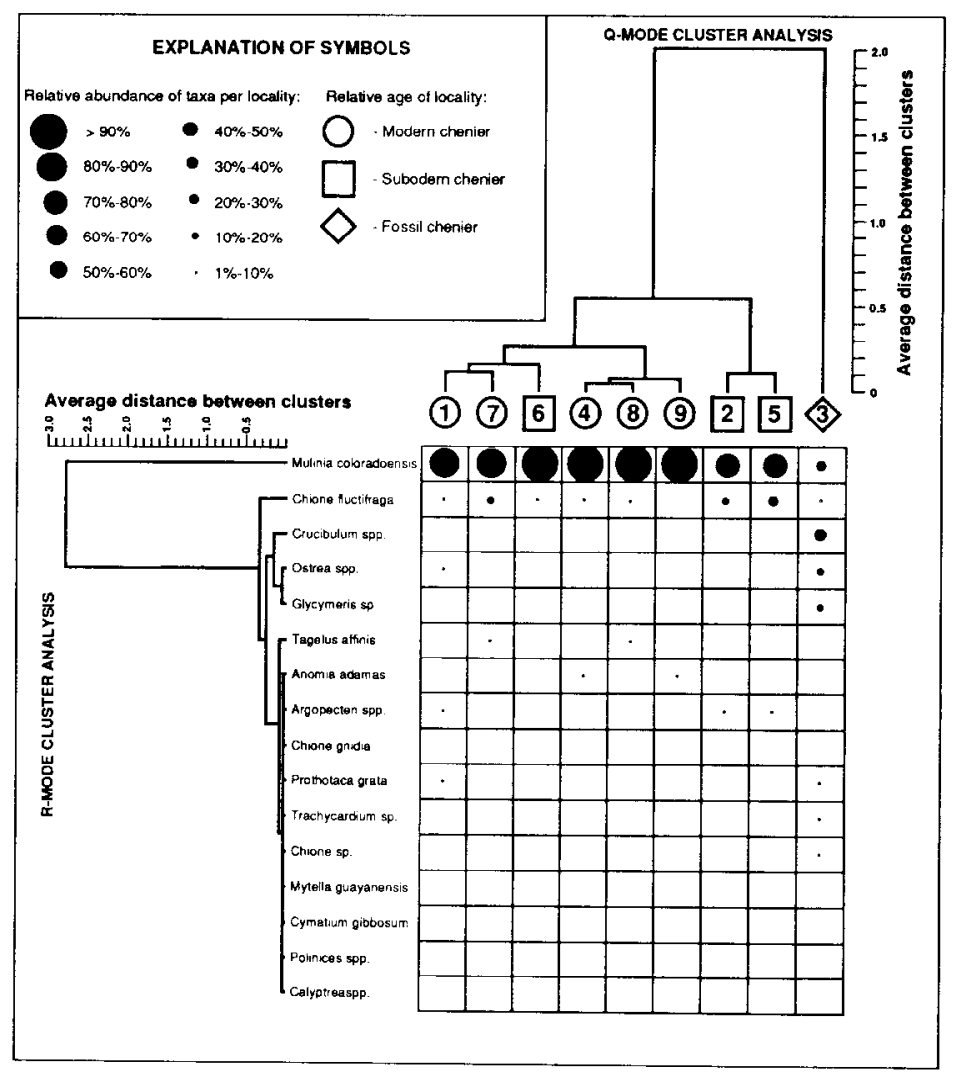

Figure 2. Two-way cluster analysis on taxonomy of molluscan shells collected from nine localities from the three generations of cheniers. Black circles indicate relative abundance of taxa in localities. Q-mode diagram shows relations among localities as determined by their taxonomic similarity (note that localities group consistently with their age except locality 6 ). 'R-mode diagram shows relations among the 16 most common taxa according to the similarities in their distribution among localities.

Figura 2. Análisis bidireccional de conjuntos sobre la taxonomía de las conchas de moluscos recolectadas en nueve localidades de tres generaciones de cheniers. Los círculos negros indican la abundancia relativa de los taxa presentes en las localidades. El diagrama de modo $Q$ muestra las relaciones entre las localidades según las determinó su similitud taxonómica (nótese que las localidades se agrupan consistentemente por su edad, excepto la localidad 6). El diagrama de modo $\mathbf{R}$ muestra las relaciones entre los 16 taxa más comunes de acuerdo con las similitudes en su distribución entre localidades.

age-inconsistent grouping may be an effect of the relatively small sample size of locality 6 $(\mathrm{n}=123.5)$. The R-mode analysis separates $M$. coloradoensis from all other taxa (fig. 2). Mulinia coloradoensis is distinct due to its domi- son raros en las otras localidades: Ostrea spp., Crucibulum spp. y Glycymeris sp. El segundo grupo incluye a todas las demás localidades. Estas ocho localidades representan tanto a las crestas modernas como a las submodernas y 


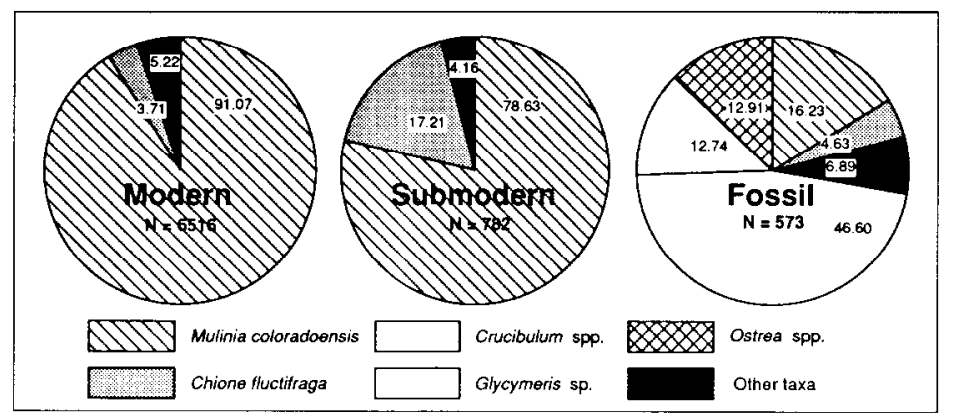

Figure 3. Taxonomic comparison of the three generations of cheniers. Numbers inside pie-charts show relative abundance of taxa per chenier generation.

Figura 3. Comparación taxonómica de las tres generaciones de cheniers. Los números dentro de los diagramas de pastel muestran la abundancia relativa de los taxa para cada generación de chenier.

nance in all submodern and modern localities and its less-frequent occurrence in the fossil ridges. The second cluster contains the remaining 15 taxa. Chione fluctifraga shows no clear association with any other taxon. On the other hand, Crucibulum spp., Ostrea spp. and Glycymeris $\mathrm{sp}$. cluster together as a result of their co-occurrence in the fossil ridge and their rarity elsewhere.

The taxonomic composition of the three generations of cheniers is shown in the piecharts (fig. 3). Note that taxonomic composition of the fossil ridges is drastically different from that of the two younger generations. On the other hand, the composition of the modern and submodern cheniers is very similar. However, submodern cheniers have a smaller proportion of M. coloradoensis and a higher proportion of C. fluctifraga. Although this difference seems small when comparing the pie-charts (fig. 3), it is in fact highly significant (using G-test for contingency tables): $\mathrm{p}<0.0001, \chi^{2}=38.886$, $\mathrm{DF}-2$

\section{Discussion}

The taxonomic structure of a chenier can be viewed as the result of three factors: 1) taxonomic composition of the nearshore benthic ecosystems that are the principal source of the shell material in the cheniers; 2) pre- están dominadas por una sola especie de bivalvo: $M$. coloradoensis (de $76 \%$ en la localidad 5 a $95 \%$ en la localidad 8). Fl segundo taxon más común, Chione fluctifraga, comprende del $0.3 \%$ de los ejemplares, en la localidad 9, al $22 \%$ de la localidad 5). Las localidades modernas y submodernas pueden a su vez ser subdivididas en tres grupos de segundo orden (fig. 2). Estas asociaciones son principalmente controladas por cambios en la abundancia relativa de $M$. coloradoensis. Dos de los tres conjuntos secundarios agrupan las localidades de acuerdo con su edad relativa. Sin embargo, el conjunto restante (localidades con 85 a $90 \%$ de $M$. coloradoensis) agrupa una localidad submoderna (6) junto con dos localidades modernas $(1,7)$. Este agrupamiento de edades inconsistentes puede ser resultado del tamaño relativamente pequeño de la muestra de la localidad $6(\mathrm{n}=$ 123.5). El análisis de modo $\mathrm{R}$ separa a $M$. coloradoensis de todos los demás taxa (fig. 2). $M$. coloradoensis se distingue debido a su dominio en todas las localidades submodernas y modernas y su menor frecuencia en las crestas fósiles. El segundo conjunto contiene a los 15 taxa restantes. C. fluctifraga no muestra una clara asociación con ningún otro taxón. Por otro lado, Crucibulum spp., Ostrea spp. y Glycymeris sp. forman un conjunto, como resultado de su coincidencia en la cresta fósil y su rareza en las otras. 
depositional taphonomic processes that include necrolysis and biostratinomy and that determine which taxa from the source ecosystems are incorporated into cheniers (these processes are responsible for the loss of the soft-bodied fauna and they may alter the relative proportion of the shelly taxa by the selective destruction and differential transport of shells); and 3) postdepositional taphonomic processes (predominately winnowing and weathering) that alter the taxonomic composition of shelly faunas after their incorporation in cheniers by the selective destruction and removal of more fragile and/or smaller taxa.

The variation in the taxonomic composition of cheniers is easily explained by these three factors. The taxonomically similar modern and submodern beach ridges are both, as indicated by radiocarbon dates, comprised of shells from the same time interval, the last 1,500 years. Thus, they represent the time-averaged record of the same interval in the history of the local benthic ecosystems. Moreover, because they are often only separated by a tidal channel or a narrow strip of tidal flats, mixing of shells is likely. A significantly larger proportion of $C$. fluctifra$g a$ in submodern cheniers when compared with the modern ones is most likely the result of post-depositional processes. Compared with $M$. coloradoensis, C. fluctifraga has a much more robust and heavy shell. The composition of the submodern ridge may have been altered by preferential removal and destruction (through weathering and winnowing) of $M$. coloradoensis shells.

The differences between the modern and submodern generations of cheniers and the fossil generation are much more substantial. The fossil ridges, situated in close proximity to the piedmont plain and formed from shells 2,000 to almost 5,000 years old, were generated by the reworking of tidal flats that were much coarsergrained than the modern, fine-sand- and siltdominated flats. The occurrence of Crucibulum spp., Glycymeris sp. and Ostrea spp. in the fossil cheniers and their virtual absence in the two younger generations of beach ridges is, therefore, not surprising. These three taxa prefer coarser substrates and higher energy environ-
La composición taxonómica de las tres generaciones de cheniers se muestra en lus diagramas de pastel (fig. 3). Obsérvese que la composición de las crestas fósiles es drásticamente diterente de la de las dos generaciones más jóvenes. Por otra parte, la composición de los cheniers modernos y submodernos es muy similar. Sin embargo, los cheniers submodernos contienen menor proporción de $M$. coloradoensis y mryor de C. fluctifraga. Aunque estas diferencias parecen pequeñas al comparar los diagramas de pastel (fig. 3), es en realidad altamente significativa (al usar las tablas de contingencia de la prueba $G$ ): $p<0.0001, \chi^{2}=$ $38.886, \mathrm{DF}=2$.

\section{DISCUSIÓN}

La estructura taxonómica de un chenier puede ser vista como resultado de tres factores: 1) la composición taxonómica de los ecosistemas bentónicos costeros, que son la principal fuente de conchas para los cheniers; 2) los procesos tafonómicos predeposicionales, que incluyen necrólisis y bioestratinomía, y que determinan cuáles taxa de los ecosistemas proveedores son incorporados a los cheniers (estos procesos son responsables de la pérdida de la fauna carente de esqueletos y pueden alterar la proporción relativa de los taxa con concha por la destrucción selectiva y transporte diferencial de las conchas); y 3) procesos tafonómicos posdeposicionales (predominantemente, acción eólica e intemperismo) que alteran la composición taxonómica de la fauna con concha después de su incorporación a cheniers, por la destrucción selectiva y remoción de los taxa más frágiles y pequeños.

La variación en la composición taxonómica de los cheniers es explicable por estos tres factores. La similitud taxonómica de las crestas de playa modernas y submodernas están, como lo indican sus edades de radiocarbono, compuestas de conchas del mismo intervalo de tiempo, los últimos 1,500 años. Por tanto, representan el registro promedio del mismo periodo en la historia de los ecosistemas bentónicos locales. Más aún, debido a que con frecuencia sólo están separados por canales de marea o 
ments. Species of Crucibulum live attached to pebbles, boulders or dead shells (Brusca, 1980) in coarser substrate and higher energy waters than that of the modern tidal flats. Glycymeris is a shallow burrower (Morton, 1967) that typically inhabits sandy shores (e.g., Parker, 1964; Brusca, 1980). Glycymeris occurs today in the sandy environments south of San Felipe (Miguel Téllez personal communication) where the piedmont plain occurs in close proximity to the shoreline and wave energy is high. Oysters are also typically found in higher energy environments and coarser substrates than the modern flats (Stenzel, 1971). In addition to ecologically induced changes in the taxonomic composition of the source ecosystems, preferential winnowing and weathering of relatively thin-sheiled $M$. coloradoensis may have enhanced the taxonomic differences between fossil and younger cheniers.

\section{TAPHONOMIC ANALYSIS}

\section{Results}

The taphonomic data set includes 4,334 observations described by nine taphonomic variables from nine localities and 61 samples. Raw data are avialable in Kowalewski et al. (1994). The Q-mode cluster analysis performed at the locality level shows that taphonomic features of mollusk shells group localities consistent with their relative age (fig. 4). The only exception is submodern locality 2 , which groups together with modern locality 1 . Comparison of charts plotted within grid-cells (fig. 4) suggests that cluster associations are controlled by luster taphonomic features: the only taphonomic traits that change notably and consistently with the age of the locality. The Rmode cluster analysis groups taphonomic variables into two main associations (fig. 4). The first association (cluster A) includes luster taphonomic features and two mechanical traits (fragmentation and edge preservation). The second association (cluster B) contains bioerosion, encrustation, cracking and peeling. Cluster A contains taphonomic grades that vary across un estrecho corredor de planicies de marea, la mezcla de conchas es común. Una proporción significativamente mayor de C. fluctifraga en los cheniers submodernos en comparación con los modernos es muy probablemente el resultado de procesos posdeposicionales. Comparada con $M$. coloradoensis, C. fluctifraga posee una concha mucho más robusta y pesada. La composición de las crestas submodernas puede haber sido alterada por remoción y destrucción preferencial (mediante intemperismo y acción eólica) de las conchas de $M$. coloradoensis.

Las diferencias entre las generaciones de cheniers modernos y submodernos y la generación de chernier fósiles son mucho más notables. Las crestas fósiles, situadas en las proximidades de la planicie de piedemonte $y$ formadas por conchas de 2,000 a casi 5,000 años de antigüedad, fueron generadas por el retrabajamiento de planicies mareales compuestas por grano mucho más grueso que las planicies modernas consistentes en arena fina y limo. La presencia de Crucibulum spp., Glycymeris sp. y Ostrea spp. en los cheniers fósiles y su virtual ausencia en las generaciones más jóvenes de crestas de playa no es, por tanto, sorprendente. Estos tres taxa prefieren sustratos más gruesos y ambientes de mayor energía. Las especies de Crucibulum viven adheridas a guijarros, cantos rodados o conchas muertas (Brusca, 1980) en sustratos más gruesos y aguas de mayor energía que las de las planicies de marea modernas. Glycymeris es un horadador somero (Morton, 1967) que habita típicamente orillas arenosas (e.g., Parker, 1964; Brusca, 1980). Glycymeris se encuentra hoy en día en los ambientes arenosos del sur de San Felipe (Miguel Téllez, comunicación personal), donde las planicies de piedemonte están próximas a la línea de costa y la energía de oleaje es alta. También es típico encontrar ostiones en ambientes de mayor energía y sustrato más grueso que en las planicies modernas (Stenzel, 1971). Además de los cambios inducidos ecológicamente en la composición taxonómica de los ecosistemas proveedores, la acción élica preferencial y el intemperismo sobre $M$. coloradoensis, cuya concha es relativamente delgada, puede haber 


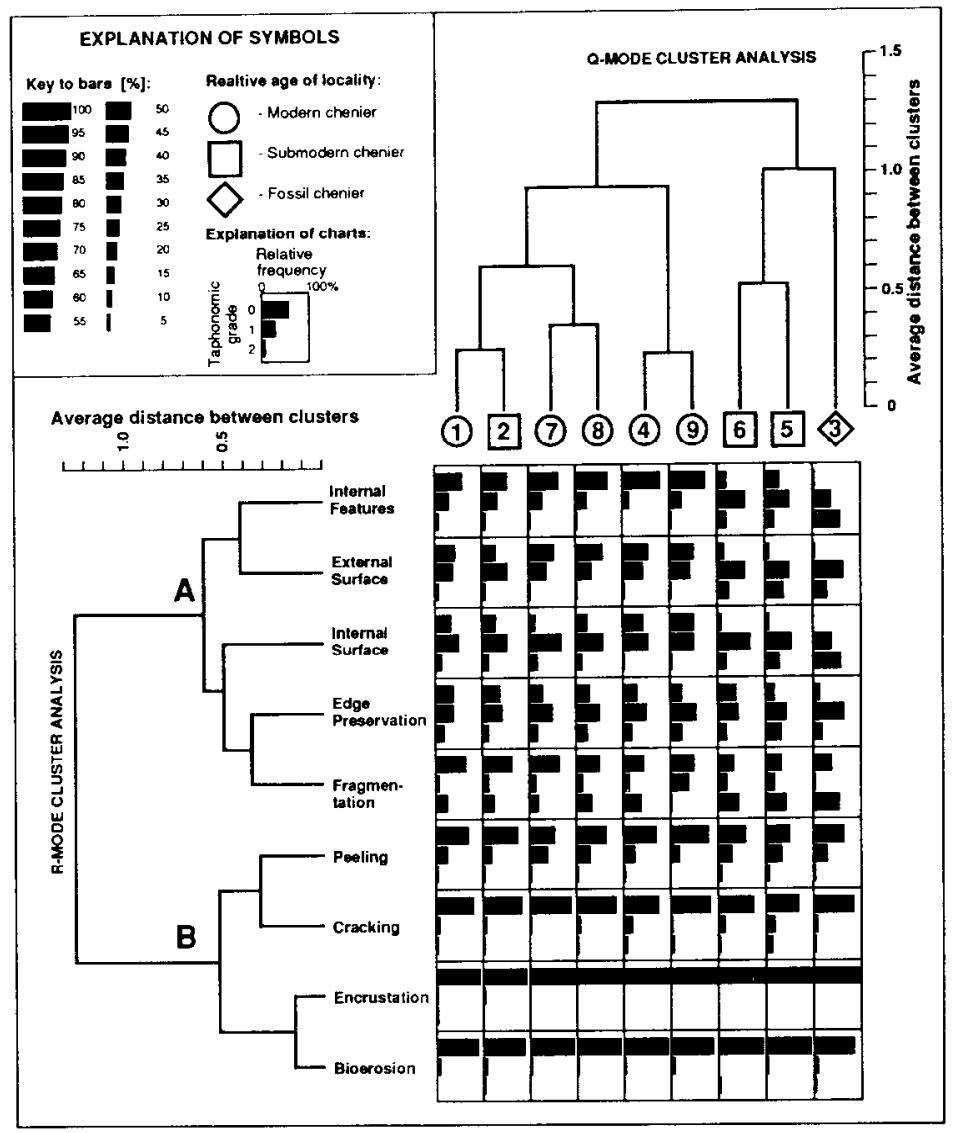

Figure 4. Two-way cluster analysis on taphonomy of shells of Mulinia coloradoensis collected from nine localities from the three generations of cheniers. Black charts indicate relative frequency of taphonomic grades in localities. Q-mode diagram shows relations among localities as determined by their taphonomic similarity (note that localities group consistently with their age except locality 2 ). $\mathrm{R}$-mode diagram shows relations among taphonomic variables, grouping them according to their variation among localities.

Figura 4. Análisis bidireccional de conjuntos de la tafonomía de las conchas de Mulinia coloradoensis recolectadas en nueve localidades de tres generaciones de cheniers. Las barras negras indican la frecuencia relativa de los grados tafonómicos en las localidades. El diagrama de modo Q muestra las relaciones entre localidades tal y como lo determina su similitud tafonómica (nótese que las localidades se agrupan consistentemente por edad, excepto la localidad 2). El diagrama de modo $\mathrm{R}$ muestra las relaciones entre las variables tafonómicas que se agrupan de acuerdo con su variación entre localidades. 
localities and cluster B contains all those variables that show very limited (if any) variability across localities.

Principal component analysis (PCA) at the sample level confirms the results of the lower resolution locality-level cluster analysis (fig. 5a). The samples group consistently with their age along principal component 1 . The only exceptions are three samples from locality 2 that occur among the modern samples. Canonical variate analysis (CVA) shows that the three cheniers, as characterized by nine taphonomic variables, are statistically different (Kowalewski et al., 1994). Subsequently, multivariate analyses PCA and CVA were repeated excluding the luster taphonomic features (i.e., variables that have a very low fossilization potential). Although the variation of samples in terms of their biological and mechanical features is less consistent with age (fig. 5b), the cheniers are still statistically distinguishable (Kowalewski et al., 1994).

Do shells currently exposed on the chenier surface differ in preservation from shells found in the subsurface? Surface and subsurface samples were compared separately for modern and submodern chenier generations (the fossil chenier was excluded due to insufficient sample size). The comparison was made separately for seven of the nine taphonomic variables (bioerosion and encrustation, two variables that show very little variation, were excluded from the comparison). Subsurface shells are better preserved for five out of seven variables in the modern cheniers and for all seven variables analyzed in the submodern cheniers. The differences in preservation between surface and subsurface shells are comparable in magnitude to the differences between the shells from different chenier generations. The comparison indicates that taphonomic alteration (especially the loss of luster) is largely a surface phenomenon. It is worth noting that the taphonomic differences between surface and subsurface samples are bound to introduce noise into the data. The proportion of subsurface shells varies among localities; localities that include a larger proportion of subsurface shells have fewer poorly preserved shells than the localities that permitido las diferencias taxonómicas entre los cheniers fósiles y los más jóvenes.

\section{ANÁLISIS TAFONÓMICO}

\section{Resultados}

El banco de datos tafonómicos incluye 4,334 observaciones descritas por nueve variables tafonómicas de nueve localidades y 61 muestras. La información original se encuentra en Kowalewski et al. (1994). El análisis de conjuntos de modo $Q$, realizado en el nivel de la localidad muestra que los caracteres tafonómicos de las conchas de moluscos se agrupan en las localidades de acuerdo con su edad relativa (fig. 4). La única excepción es la localidad submoderna 2 (que se agrupa con la localidad moderna 1). La comparación de los diagramas graficados dentro de celdas (fig. 4) sugiere que las asociaciones de conjuntos están controladas por los rasgos de lustre: la única cualidad tafonómica que cambia notable y consistentemente con la edad de la localidad. El análisis de conjuntos de modo $\mathrm{R}$ agrupa las variables en dos asociaciones principales (fig. 4). La primera asociación (conjunto $A$ ) incluye rasgos tafonómicos de lustre $\mathrm{y}$ dos cualidades mecánicas (fragmentación y preservación de la orilla). La segunda asociación (conjunto B) contiene bioerosión, incrustación, fracturamiento y desconchamiento. El conjunto A contiene grados tafonómicos que varían a través de las localidades y el conjunto $\mathrm{B}$ contiene todas las variables que muestran variabilidad muy limitada (si alguna) entre las localidades.

El análisis de componente principal a nivel de muestra confirma los resultados de menor resolución, el análisis de conjuntos a nivel localidad (fig. 5a). Las muestras se agrupan consistentemente por su edad a lo largo del componente principal 1. Las únicas excepciones son tres muestras modernas de la localidad 2. El análisis de variable canónica (CVA) muestra que los tres cheniers caracterizados por las nueve variables son estadisticamente diferentes (Kowalewski et al., 1994). Posteriormente se repitieron los análisis de multivariables PCA y CVA excluyendo los rasgos ta- 

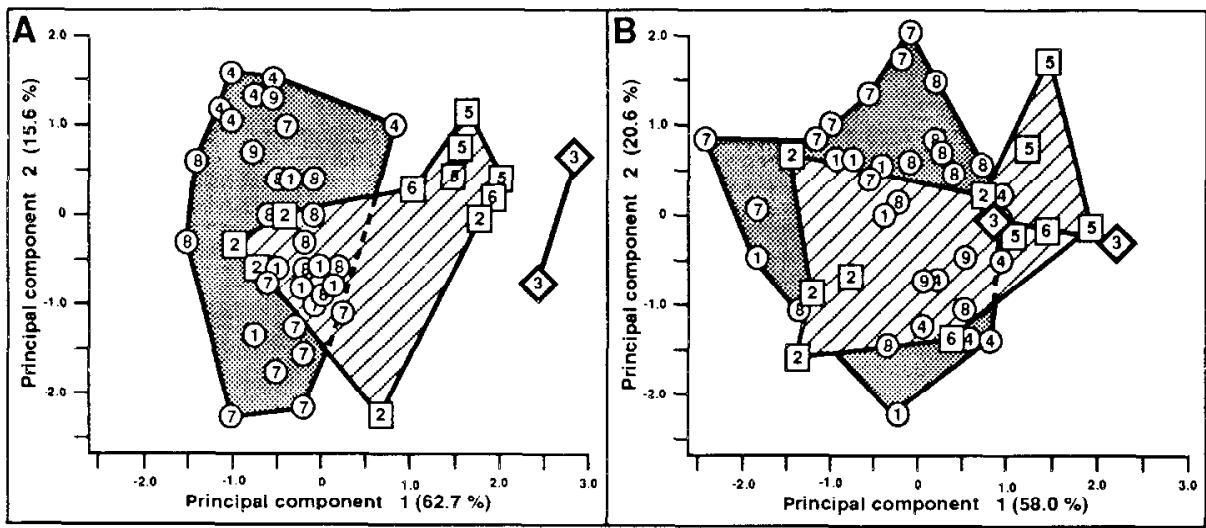

Figure 5. Principal component ordination of samples for taphonomic variables describing preservation of Mulinia coloradoensis collected from the cheniers of northeastern Baja California. Each number represents a single sample and identifies the locality from which that sample was collected. Symbols: $O=$ modern chenier; $\square=$ submodern chenier; $0=$ fossil chenier. Principal component ordination: A, for all nine taphonomic variables; $\mathrm{B}$, for six preservable variables only (i.e., excluding luster features).

Figura 5. Ordenamiento de componente principal de muestras por variables tafonómicas que describen la preservación de Mulinia coloradoensis recolectada en los cheniers) del noreste de Baja California. Cada número representa una sola muestra e identifica la localidad de la cual proviene la muestra. Símbolos: $O=$ chenier moderno; $\square=$ chenier submoderno; $\diamond=$ chenier fósil. Ordenamiento de componente principal: A, para las nueve variables tafonómicas; B, sólo para las seis variables preservables (i.e., excluyendo los rasgos de lustre).

include mostly surface data. The proportion of subsurface shells is low (below 20\%) for all localities except submodern locality $2(67 \%)$. Thus, the inconsistently low taphonomic alteration found for locality 2 (figs. 4,5 ) is most likely a sampling artifact.

\section{Origin of taphonomic features}

The post-mortem modifications of shells can be classified in three groups of biological, mechanical and luster modifications. Because they result from different processes, it is appropriate to discuss those three groups separately.

Biological alteration of shells induced by bioeroding (fungi, algae, sponges, bryozoa, polychaetes, and molluscs) and encrusting (coralline algae, foraminifera, coelenterates, bryozoa, mollusks, and barnacles) organisms is common in marine environments (e.g., Driscoll, fonómicos (i.e., variables que tienen un potencial de fosilización muy bajo). Aunque la variación de las muestras en términos de sus rasgos biológicos y mecánicos es menos consistente con la edad (fig. 5b), los cheniers son todavía estadísticamente distinguibles (Kowalewski et al., 1994).

¿Las conchas encontradas en la subsuperficie difieren en preservación de las conchas actualmente expuestas en la superficie de los cheniers? Muestras de superficie y subsuperficie de las generaciones de cheniers modernos y submodernos fueron comparadas separadamente (el chenier fósil fue excluido debido al insuficiente tamaño de la muestra). La comparación se hizo por separado para siete de las nueve variables tafonómicas (bioerosión $\mathrm{e}$ incrustación, dos variables que mostraron muy poca variación, fueron excluidas de la comparación). Las conchas subsuperficiales muestran mejor preservación para cinco de las siete varia- 
1970; Golubic et al., 1975; Warme, 1975). The very low frequency of bioerosion and encrustation in chenier shell assemblages is not surprising. The initial source of shells, a fine-grained nearshore tidal flat dominated by infaunal organisms and extensive bioturbation, is not a suitable habitat for the bioeroding and encrusting organisms more typical of epifaunal communities. Even though the cheniers offer a suitablc substrate for the epibionts, they form in the supratidal zone and are covered by water for only short intervals of time during spring high tides. Thus, the colonization of cheniers by bioeroding and encrusting organisms is also prevented. The rare bioeroded and/or encrusted shells found in the samples were most likely transported by longshore drift from the rocky shores to the south.

Mechanical features of shells such as fragmentation, cracking and abrasion are effects of physical processes responsible for movement and collisions of shells with other sedimentary particles (e.g., Schäfer, 1972; Dodd and Stanton, 1990). These features may also be caused by predators such as birds and crabs (e.g., Cadée, 1968; Carter, 1974). The moderate mechanical alteration, practically identical for all three generations of cheniers, suggests that the alteration most likely took place during the initial biostratinomic stage. If mechanical alteration during the weathering stage was important, greater taphonomic differences between chenier generations would be likely. Mechanical alteration of shells resulted most likely from both physical processes (currents and waves generated by storms and tides) and predation (crabs and shorebirds are both common in the study area).

The loss of luster which results in a chalky appearance of the shell surface stems from dissolution and maceration (Alexandersson, 1972, 1979; Lewy, 1981; Aller, 1982; Cutler, 1991). The fact that the proportion of chalky shells increases with chenier age indicates that the loss of luster occurs mostly during the subaerial weathering stage. This loss is most likely caused by meteoric waters (Walker, 1979). The luster features are discussed in detail by Kowalewski et al. (1994). bles en el caso de los cheniers modernos y para todas ellas en el caso de los cheniers submodernos. Las diferencias en preservación entre las conchas superficiales y las subsuperficiales son comparables en magnitud a las diferencias entre las conchas de diferentes generaciones de cheniers. I a comparación indica que la alteración tafonómica (en especial, la pérdida de lustre) es principalmente un fenómeno superficial. Vale la pena notar que las diferencias tafonómicas entre las muestras superficiales y subsuperficiales están destinadas a introducir ruido en los datos. La proporción de conchas subsuperficiales varía entre localidades: las localidades que incluyen una gran proporción de conchas subsuperficiales contienen menos conchas pobremente preservadas que las localidades que incluyen principalmente datos de superficie. La proporción de conchas subsuperficiales es baja (menos del $20 \%$ ) para todas las localidades excepto para la localidad submoderna $2(67 \%)$. Por tanto, la alteración tafonómica inconsistentemente baja encontrada en la localidad 2 (figs. 4,5 ) es muy probablemente un artificio de muestreo.

\section{Origen de las características tafonómicas}

Las modificaciones post mortem de las conchas pueden ser clasificadas en tres grupos: biológicas, mecánicas y de lustre. Debido a que resultan de diferentes procesos, es conveniente discutirlas separadamente.

La alteración biológica de las conchas inducida por organismos bioerosionantes (hongos, algas, esponjas, briozoarios, poliquetos y moluscos) e incrustantes (algas coralinas, foraminíferos, celenterados, briozoarios, moluscos y lapas) es común en los ambientes marinos (e.g., Driscoll, 1970; Golubic et al., 1975; Warme, 1975). La rara frecuencia de bioerosión e incrustación en los conjuntos de conchas de chenier no es sorpresiva. La fuente inicial de conchas, una planicie de marea costera de grano fino dominada por organismos infáunicos y extensa bioturbación no es un hábitat propicio para los organismos bioerosionantes e incrustantes más típicos de comunidades epifáunicas. Aunque los cheniers ofrecen un sustrato ade- 


\section{Utility of taphofacies analysis}

Multivariate analyses show that cheniers of various ages can be successfully discriminated using taphonomic criteria. Shells from the modern, submodern and fossil ridges differ consistently in their taphonomic characteristics. This suggests that the three generations of cheniers, if preserved in the fossil record, could be discriminated using the taphofacies approach.

\section{Taphonomic characteristics of chenier plain shelly lag accumulations}

Numerous studies describing molluskdefined taphofacies in a variety of modern, marine environments have been published in the last decade (e.g., Parsons and Brett, 1991; Meldahl, 1994). They include studies in a variety of environments, from coastal zone to continental slope (Parsons and Brett, 1991). The methods of taphonomic description differ greatly among the authors, and therefore, it is impossible to compare the results in a rigorous quantitative fashion. Detailed comparisons of these earlier studies can be found in Parsons and Brett (1991). The taphonomic characteristics of the chenier-plain shelly assemblages are distinct from those found for mollusk assemblages in other modern environments. The most important characteristic is an invariably low frequency of biological taphonomic alteration. The proportion of bioeroded shells does not exceed $14 \%$ for any of the localities and it is below $10 \%$ for most of the localities. The proportion of encrusted shells is even lower: it does not exceed $6 \%$ for any locality and it is less than $1 \%$ for most of the localities.

\section{Taphonomic clock}

As Brandt (1989) pointed out, preservation changes in one direction through time: from good to poor. One could expect therefore, the existence of a "taphonomic clock" (Kidwell, 1993). Taphonomic condition should indicate the amount of time that elapsed from the death of the organism until the final burial of its remains. Most taphonomic processes are deacti- cuado para los epibiontes, éstos se forman en la zona supramareal y quedan cubiertos de agua sólo por periodos breves de tiempo durante las mareas ascendentes altas. De esta manera, se evita también la colonización de cheniers por organismos bioerosionantes e incrustantes. Las escasas conchas bioerosionadas y/o incrustadas encontradas en las muestras fueron muy probablemente transportadas por corrientes costeras desde las orillas rocosas del sur.

Las características mecánicas de la concha, como fragmentación, fracturamiento y abrasión, son resultado de procesos fisicos responsables del movimiento y colisión de las conchas con otras partículas sedimentarias (e.g., Schäfer, 1972; Dodd y Stanton, 1990). Esas caracteristicas pueden también haber sido causadas por depredadores tales como aves y cangrejos (e.g., Cadée, 1968; Carter, 1974). La alteración mecánica moderada, prácticamente idéntica en las tres generaciones de cheniers, sugiere que la alteración es muy probable que haya tenido lugar durante la etapa bioestratinómica inicial. Si la alteración mecánica durante la etapa de intemperismo fuese importante, se observarian mayores diferencias tafonómicas entre las generaciones de cheniers. La alteración mecánica de las conchas es quizás resultado tanto de procesos fisicos (corrientes y oleaje generados por tormentas y mareas) como de depredación (cangrejos y aves costeras comúnes en el área de estudio).

La pérdida de lustre que produce una apariencia gredosa en la superficie de la concha es resultado de disolución y maceración (Alexandersson, 1972, 1979; Lewy, 1981; Aller, 1982; Cutler, 1991). El hecho de que la proporción de conchas gredosas aumente con la edad del chenier indica que la pérdida de lustre ocurre principalmente durante la etapa de intemperismo subaéreo. Esta pérdida puede atribuirse a disolución y maceración de la superficie de la concha, causada por aguas meteóricas (Walker, 1979). Las caracteristicas de lustre son discutidas en detalle por Kowalewski et al. (1994).

\section{Utilidad del análisis de tafofacies}

Los análisis de multivariables muestran que los cheniers de varias edades pueden ser 
vated after final burial and the taphonomic clock slows or stops. Thus, the degree of taphonomic alteration (e.g., degree of fragmentation, intensity of bioerosion, etc.) should be proportional to the duration of biostratinomic processes, and by this, imply scales of time-averaging and rates of sedimentation. In spite of these expectations, the evidence for the existence of a taphonomic clock has been occasionally found in modern environments only (Flessa, 1993). This may be caused by the fact that the remains of organisms are not continuously exposed on the surface, that taphonomic processes vary in intensity through time and across environments, and that the taphonomic clock may be too slow to be detected in actualistic studies. Taphonomic variables that are sometimes correlated with shell age include color and luster/chalkiness (Flessa, 1993; Kowalewski et al., 1994).

Individual variables show no clear correlation with chenier age (except luster features which are not preservable). However, when the six preservable variables are pooled (excluding the subsurface samples), the resulting total preservable taphonomic grade shows a temporal trend (fig. 6); the modern shells are better preserved (mean grade $=1.8$ ) than the two older generations, but the latter two do not differ from one another (both submodern and fossil ridges have mean $\approx 2.3$ ). In sum, even though the total preservable grade is a better time indicator than any of the six preservable grades individually, it is still far from perfect.

\section{CONCLUSIONS}

The three generations of cheniers differ in their age, taphonomic history and taxonomic composition. Shells accumulated in cheniers are not significantly affected by biological processes (bioerosion, encrustation), moderately affected by physical processes (fragmentation, cracking, peeling, edge preservation) and strongly affected by surface weathering. The surface weathering is manifested in the luster features of shells (external luster, internal luster and internal features), the only features that vary substantially and consistently with chenier acertadamente discriminados usando criterios tafonómicos: las conchas de las crestas modernas, submodernas y fósiles difieren consistentemente en sus caracterísiticas tafonómicas. Esto sugiere que las tres generaciones de cheniers, si se preservasen en el registro fósil podrían ser discriminadas usando el método de tafofacies.

\section{Características tafonómicas de las acumulaciones residuales tipo chenier}

Numerosos estudios que describen tafofacies definidas por moluscos en una diversidad de ambientes marinos modernos han sido publicados durante la última década (e.g., Parsons y Brett, 1991; Meldahl, 1994). Estos incluyen una variedad de ambientes de la zona costera a la plataforma continental (Parsons y Brett, 1991). Los métodos de descripción tafonómica difieren mucho entre autores, por tanto, es imposible comparar cuantitativamente los resultados de forma rigurosa. Comparaciones detalladas de estos primeros estudios se encuentran en Parsons y Brett (1991). Las características tafonómicas de los conjuntos de conchas en cheniers son distintas de las encontradas en conjuntos de moluscos de otros ambientes modernos. La característica más importante es la invariablemente baja frecuencia de alteración tafonómica biológica. La proporción de conchas bioerosionadas no excede el $14 \%$ para ninguna de las localidades y para la mayoría de ellas está por debajo del 10\%. La proporción de conchas incrustadas es aún menor: no excede el $6 \%$ para ninguna de las localidades, pero es menor de $1 \%$ para la mayoría de las mismas.

\section{Reloj tafonómico}

Como señala Brandt (1989), la preservación cambia en una dirección a través del tiempo: de buena a pobre. Uno podria esperar, por tanto, la existencia de un "reloj tafonómico" (Kidwell, 1993). La condición tafonómica debería indicar la cantidad de tiempo transcurrido desde la muerte de los organismos hasta su enterramiento final (después del cual la mayoría de los procesos tafonómicos se desactivan y el reloj 


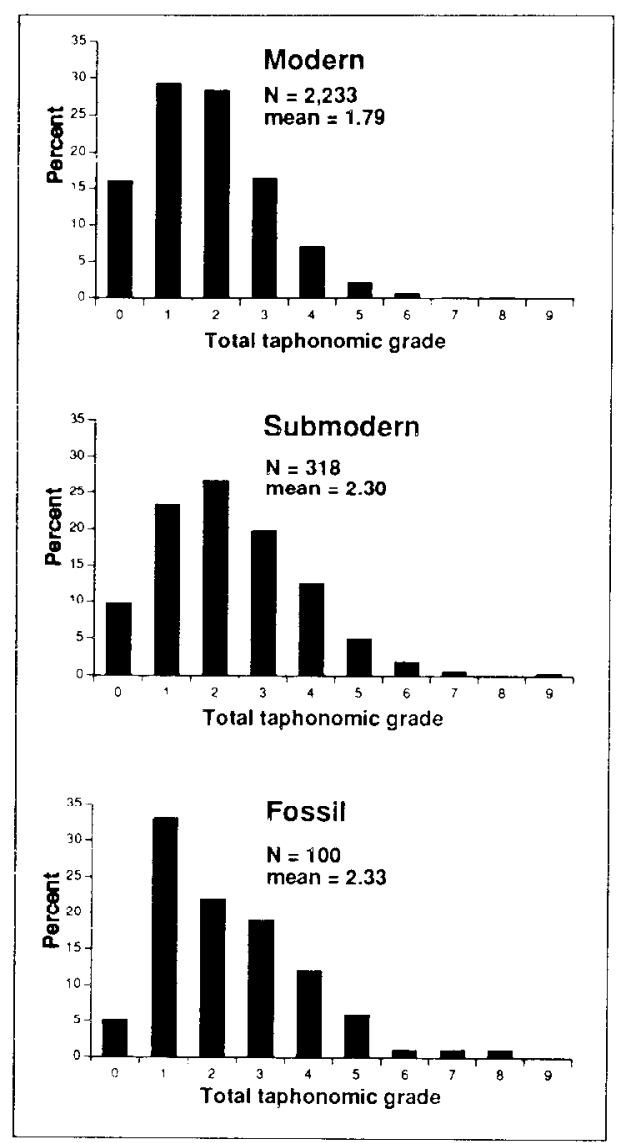

Figure 6. Taphogram (relative grade-frequency distribution) for Total Preservable Taphonomic Grade calculated as sum of six preservable taphonomic proprieties. Shells collected from subsurface are excluded from analysis. A, Modern chenier; B, Submodern chenier; C, Fossil chenier.

Figura 6. Tafograma (distribución relativa del grado de frecuencia) del grado tafonómico total de preservación calculado como la suma de las seis propiedades tafonómicas preservables. Las conchas recolectadas de la subsuperficie son excluidas de este análisis. A, chenier moderno; $\mathrm{B}$, chenier submoderno; $\mathrm{C}$, chenier fósil.

age. Chenier-plain shell assemblages are a class of taphofacies that are characterized by a very low frequency of bioerosion and encrustation.

Multivariate taphofacies analysis discriminates the three generations of cheniers. This suggests that age-consistent taphofacies discrimination is possible for fossil cheniers. The substantial taphonomic differences between subsurface and surface shells indicate that ta- tafonómico se frena o detiene). Por tanto, el grado de alteración (e.g., grado de fragmentación, intensidad de bioerosión, etc.) debe ser proporcional a la duración de los procesos bioestratinómicos $\mathrm{y}$, por ello, implica escalas temporales y tasas de sedimentación. A pesar de estas expectativas, la evidencia de la existencia de un reloj tafonómico sólo se ha encontrado raramente en ambientes modernos (Flessa, 
phonomic degradation in this chenier plain environment is a surface phenomenon.

\section{ACKNOWLEDGEMENTS}

This paper is a shortened version of Kowalewski et al. (1994). It is presented here to make our results available to scientists working in the region. We thank the editors of Facies for their permission to reproduce the figures.

We thank Miguel Téllez (Universidad Autónoma de Baja California), Tim Vidra, Tina Wells (University of Arizona) and Sally E. Walker (University of Georgia) for help in the field work. Olivia Pérez-Ramos (Universidad de Sonora) provided the air photos. We thank Tim Demko, Peter Holterhoff, Jorge Ledesma and Keith Meldahl for their helpful reviews. This research was supported by NSF grant EAR 8913442 and by the Office of International Programs, University of Arizona. We thank Manuel R. Palacios-Fest for the Spanish translation.

\section{REFERENCES}

Alexandersson, E.T. (1972). Micritization of carbonate particles: processes of precipitation and dissolution in modern shallow marine sediments. Bull. Geol. Inst. Univ. Uppsala N.S., 7: 201-236.

Alexandersson, E.T. (1979). Marine maceration of skeletal carbonates in the Skagerrak, North Sea. Sedimentology, 26: 845-852.

Aller, R.C. (1982). Carbonate dissolution in nearshore terrigenous muds: the role of physical and biological reworking. J. Geol., 90: 79-95.

Augustinus, P.G.E.F. (1989). Cheniers and chenier plains: a general introduction. Mar. Geol., 90: 219-229.

Brandt, D.S. (1989). Taphonomic grades as a classification for fossiliferous assemblages and implications for paleoecology. Palaios, 4: 303-309.

Bray, N.A. and Robles, J.M. (1991). Physical oceanography of the Gulf of California. In:
1993). Esto debe de ser causado por la discontinua exposición de los restos orgánicos a la superficie, la variación en la intensidad de los procesos tafonómicos en el tiempo y espacio (ambientes), y a que el reloj talonónico puede ser muy lento para ser detectado por estudios modernos. Las variables tafonómicas a veces asociadas con la edad de la concha incluyen el color y lustre o gredosidad (Flessa, 1993; Kowalewski et al., 1994).

Las variables individuales mejor preservadas no muestran una correlación clara con la edad del chenier (excepto las características de lustre que no se preservan). Sin embargo, cuando las seis variables susceptibles de preservación son reunidas (excluyendo las mucstras subsuperficiales), el grado de preservación tafonómica total resultante muestra una tendencia temporal (fig. 6): las conchas modernas están mejor preservadas (grado medio $=1.8$ ) que las de generaciones más antiguas, pero éstas no se distinguen una de la otra (las crestas submodernas y fósiles tienen una media $\approx 2.3$ ). En suma, aunque el grado total de preservación es mejor indicador de tiempo que cualesquiera de los otros seis grados de preservación, individualmente está aún lejos de ser perfecto.

\section{CONCLUSIONES}

Las tres generaciones de cheniers difieren en edad, historia tafonómica y composición taxonómica. Las conchas acumuladas en cheniers no resultan significativamente afectadas por procesos biológicos (bioerosión, incrustación), pero son moderadamente afectadas por procesos fisicos (fragmentación, fracturamiento, desconchamiento y preservación de la orilla) y fuertemente afectadas por intemperismo superficial. El intemperismo superficial se manifiesta en los rasgos de lustre de las conchas (lustre externo, interno y características internas), las únicas características que varían sustancial y consistentemente con la edad de los cheniers. Los conjuntos de conchas cheniers sencillos son un tipo de tafofacies que se caracterizan por frecuencias muy bajas dc bioerosión e incrustación. 
J.P. Dauphin and B.R.T. Simoneit (eds.), Amer. Assoc. Petr. Geol. Memoir, 47: 511-553.

Brett, C.E. and Baird, G.C. (1986). Comparative taphonomy: A key for paleoenvironmental reconstruction. Palaios, 1: 207-227.

Brusca, R.C. (1980). Common Intertidal Invertebrates of the Gulf of California, 2nd Ed., The University of Arizona Press, 513 $\mathrm{pp}$.

Cadée, G.C. (1968). Molluscan biocoenoses and thanatocoenoses in the Ria de Arosa, Galicia, Spain. Zool. Verh. Leiden, 95: 1-121.

Carter, R.W.G. (1974). Feeding sea birds as a factor in lamellibranch valve sorting pattern. J. Sed. Petrol., 44: 689-692.

Cutler, A.H. (1991). Processes of hardpart breakdown and models of stratigraphic disorder in shallow marine environments. Ph.D. Dissertation, University of Arizona, Tucson, Arizona, USA, $256 \mathrm{pp}$.

Dodd, J.R. and Stanton, R.J., Jr. (1990). Paleoecology, Concepts and Applications, 2nd Ed., Wiley, 502 pp.

Driscoll, E.G. (1970). Selective bivalve shell destruction in marine environments, a field study. J. Sed. Petrol., 40: 898-905.

Dunteman, G.H. (1989). Principal Component Analysis, 1st Ed., Sage, 96 pp.

Flessa, K.W. (1993). Time-averaging and temporal resolution in Recent marine shelly faunas. In: S.M. Kidwell and A.K. Behrensmeyer (eds.), Short Courses in Paleontology, 6: 9-33.

Gastil, R.G., Philips, R. and Allison, E. (1975). Reconnaissance geology of the state of Baja California. Geol. Soc. Amer. Memoir, 140: 1-170.

Golubic, S, Perkins, R.D. and Lukas, K.J. (1975). Boring microorganisms and microborings in carbonate substrates. In: R.W. Frey (ed.), The Study of Trace Fossils: A Synthesis of Principles, Problems and Procedures in Ichnology. SpringerVerlag, pp. 229-259.

Kidwell, S.M. (1991). The stratigraphy of shell concentrations. In: P.A. Allison and D.E.G. Briggs (eds.), Topics in Geobiology, 9: 211-290.
El análisis multivariable de tafofacies discrimina las tres generaciones de cheniers. Esto sugiere que la discriminación de tafofacies de edad equivalente es posible en los cheniers fósiles. Las diferencias tafonómicas significativas entre las conchas superficiales y subsuperficiales indican que la degradación en el ambiente de chenier es un fenómeno de superficie

\section{AGRADECIMIFNTOS}

Este trabajo, versión reducida de Kowalewski et al. (1994, se presenta aqui con la intención de poner los resultados a disposición de los científicos que trabajan en esta región. Se agradece a los editores de Facies el permiso para reproducir las figuras.

Gracias a Miguel Téllez (UABC), Tim Vidra, Tina Wells (ambos de la Universidad de Arizona) y Sally E. Walker (Universidad de Georgia) por su ayuda en el campo. Olivia Pérez Ramos (Universidad de Sonora) proporcionó las fotografías aéreas. Gracias a Tim Demko, Peter Holterhoff, Jorge Ledesma y Keith Meldahl, por sus valiosas contribuciones para mejorar este manuscrito. El trabajo fue financiado por NSF, mediante la subvención EAR 8913442 y por la Oficina de Programas Internacionales de la Universidad de Arizona. Se agradece la traducción realizada por Manuel R. Palacios Fest.

Traducción presentada por los autores.

Kidwell, S.M. (1993). Patterns of timeaveraging in the shallow marine fossil record. In: S.M. Kidwell and A.K. Behrensmeyer (eds.), Short Courses in Paleontology, 6: 275-300.

Kowalewski, M., Flessa, K.W. and Aggen, J.A. (1994). Taphofacies analysis of Recent mollusk lag concentrations: Bivalve preservation and relative age of shelly cheniers on the tidal flats of northeastern Baja California, Mexico. Facies, 31: 209-242.

Lewy, Z. (1981). Maceration of skeletal carbonates. Sedimentology, 28: 893-895. 
Meldahl, K.H. (1993). Geographic gradients in the formation of shell concentrations: PlioPleistocene marine deposits, Gulf of California. Palaeogeogr. Palaeoclimat. Palaeoecol., 101: 1-25.

Meldahl, K.H. (1994). Biofacies and taphofacies of a Holocene macrotidal environment: Bahía La Cholla, northern Gulf of California. Ciencias Marinas, 20(4): 555-583.

Meldahl, K.H. (1995). Pleistocene shoreline ridges from tide-dominated and wavedominated coasts: northern Gulf of California and western Baja California, Mexico. Marine Geology, in press.

Morton, J.E. (1967). Molluscs, 4th Ed., Hutchison, $244 \mathrm{pp}$.

Parker, R.H. (1964). Zoogeography and ecology of some macroinvertebrates particularly mollusks, in the Gulf of California and the continental slope of Mexico. Vidensk. Medd. Dansk. Naturh. Foren., 126: 1-178.

Parsons, K.M. and Brett, C.E. (1991). Taphonomic processes and biases in modern marine environments: an actualistic perspective on fossil assemblage preservation. In: S.K. Donovan (ed.), The Processes of Fossilization. Columbia University Press, pp. 22-65.

Statistical Analysis System Institute (SAS) (1989). SAS/Stat User's Guide: Version 6, 4th Ed., SAS Institute, Vol. 1, 943 pp. and Vol. 2, $846 \mathrm{pp}$.
SAS Institute (1990). SAS Procedures Guide: Version 6, 3rd Ed., SAS Institute, 705 pp.

Schäfer, W. (1972). Ecology and Paleoecology of Marine Environments, 1st Ed., University of Chicago Press, $568 \mathrm{pp}$.

Speyer, S.E. and Brett, C.E. (1986): Trilobite taphonomy and Middle Devonian taphofacies. Palaios, 1: 312-327.

Stenzel, H.B. (1971). Oysters. In: R.C. Moore (ed.), Treatise on Invertebrate Paleontology, Part N: N953-N1224, University of Kansas Press.

Suárcz-Vidal, F., Armaijo, R., Morgan, G., Bodin, P. and Gastil, G.R. (1991). Framework of Recent and active faulting in northern Baja California. In: J.P. Dauphin and B.R.T. Simoneit (eds.), Amer. Assoc. Petr. Geol. Memoir, 47: 285-300.

Thompson, R.W. (1968). Tidal flat sedimentation on the Colorado River delta, Northwestern Gulf of California. Geol. Soc. Amer. Memoir, 107: 1-133.

Warme, J.E. (1975). Borings as trace fossils and the processes of marine bioerosion. In: R.W. Frey (ed.), The Study of Trace Fossils: A Synthesis of Principles, Problems and Procedures in Ichnology. SpringerVerlag, pp. 181-227.

Walker, B.M. (1979). Shell dissolution: destructive diagenesis in a meteoric environment. Scanning Electron Microscopy, 1979/II: 463-468.

Walker, T.R. and Thompson, R.W. (1968). Late Quaternary geology of the San Felipe area, Baja California, Mexico. J. Geol., 76: 479-485. 